\title{
Cervical Lymph Nodal and Esophageal Metastasis in a Patient with Primary Ovarian Carcinoma:
}

\section{A Case Report}

\author{
Erkan ARPACI ${ }^{1}$, F. Tugba KOS ${ }^{1}$, Tarkan YETISYIGIT ${ }^{1}$, S. Cigdem IRKKAN ${ }^{2}$, Isin PAK ${ }^{2}$, \\ Fatma PAKSOY ${ }^{1}$, Arife ULAS ${ }^{1}$, Saadet TOKLUOGLU ${ }^{1}$, Gokhan CELENKOGLU ${ }^{1}$, Necati ALKIS ${ }^{1}$ \\ ${ }^{1}$ Ankara Onkoloji Training and Research Hospital, Department of 1th Medical Oncology \\ ${ }^{2}$ Ankara Onkoloji Training and Research Hospital , Department of Pathology, Ankara, TURKEY
}

\begin{abstract}
Secondary carcinoma of the esophagus occur as a result of direct invasion from a primary tumor of an adjacent structure, invasion from metastatic foci in mediastinal lymph nodes or metastatic hematogenous spread. We report a 40 year old female operated because of the primary ovarian carcinoma and who was admitted with swelling on the neck after five years and with disphagia after eight years since onset of the ovarian resection during the follow-up. She was considered inoperable and only chemotherapy is being administered.
\end{abstract}

Keywords: Esophagus metastasis, Ovarian carcinoma

\section{ÖZET}

Primer Over kanserli Bir Hastada servikal Lenf Nodu ve Özefagus Metastazı: Bir Olgu Sunumu

Özofagusun sekonder kanserleri komşu bir dokunun primer kanserinin direkt inazyonu, mediastinal lenf nodlarındaki metastatik odakların invazyonu veya metastatik hematojen yayılma sonucu olmaktadır. Primer over kanseri nedeniyle opere olmuş ve takiplerinde over rezeksiyonu başlangıından 5 yıl sonra boyunda şişlik ve 8 yıl sonra da disfaji ile başvuran 40 yaşında bir kadın olgu bildirdik. İnoperabl kabul edilen hasta halen sadece kemoterapi almaktadır.

Anahtar Kelimeler: Özofagus metastazı, Over kanseri 


\section{INTRODUCTION}

Secondary esophageal carcinoma occurs in about $3 \%$ of patients dying with carcinoma. ${ }^{1.2}$ Esophageal invasion by secondary carcinoma produces obstruction and symptoms that frequently mimic a benign stricture or primary esophageal carcinoma. However, the radiographic findings produced by secondary esophageal tumors are usually sufficiently specific that the radiologist can make the correct diagnosis. Local treatment for metastatic lesions in the esophagus from other organs usually cannot be justified because such lesions are often manifestations of systemic disease or mediastinal carcinomatosis. Recently, however, surgical resection was reported to provide excellent palliative therapy and long survival. ${ }^{3.4}$ Combined chemotherapy and radiotherapy is the standard of care in the nonsurgical management of esophageal cancer.

\section{CASE REPORT}

A 40-year-old woman with twelve years history of primary infertility was admitted to a medical center with distention of the abdomen, pelvic pain and na-

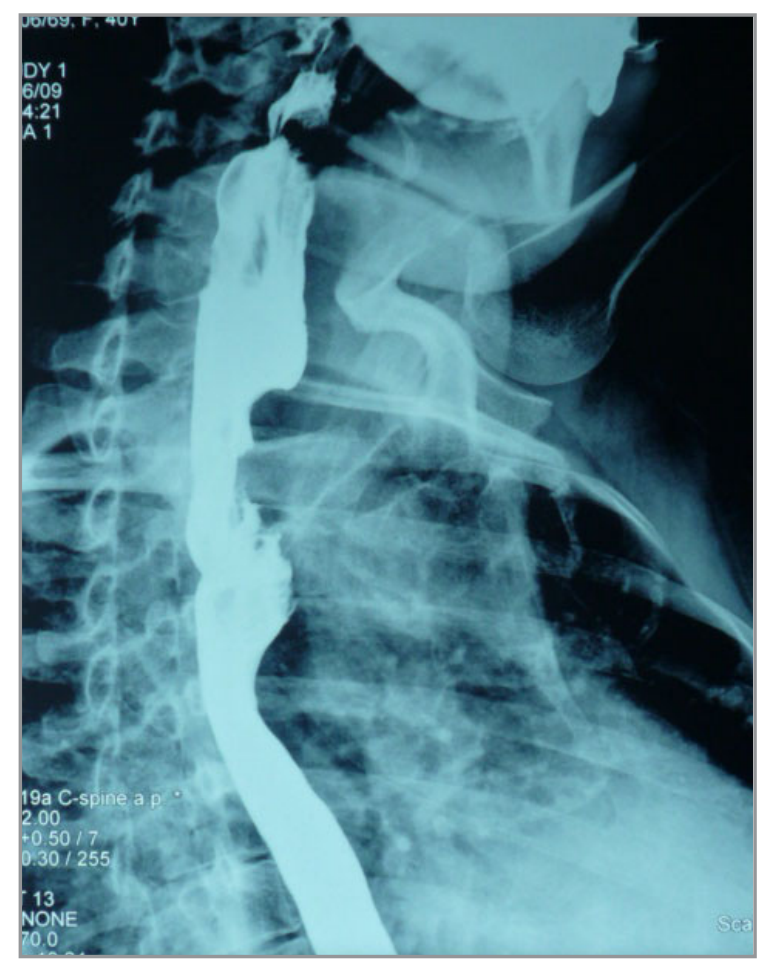

usea since two months. On the pelvic ultrasonography a mass was found and the patient underwent bilateral salpingo-oophorectomy and omentectomy . Histopathological diagnosis was reported as clear cell carcinoma of the left ovary, with the tumor confined to the ovary. She was administered two cycles of chemotherapy including platin plus taxane, and then four cycles of chemotherapy including platin plus cyclophosphamide at that center. After the chemotherapy had finished she was offered for second-look laparotomy but she didn't accept the operation. Five years later from the first diagnosis she was admitted to our hospital with swelling on the neck because of cercival lymphadenopathies. A biopsy was performed and histopathologic finding revealed carcinoma metastasis with CA125 positivity that considered as metastasis of ovarian carcinoma. She was treated with chemotherapy consisted of combined platin and taxane about 6 cycles. At the follow-up five months later locally relapsing occured that confirmed with fine needle biopsy. She was administered second choice chemotherapy including liposomal doxorubicin for four cycles. After 3 months of the termination of chemotherapy mediastinal lymphadenopaties were found in com-

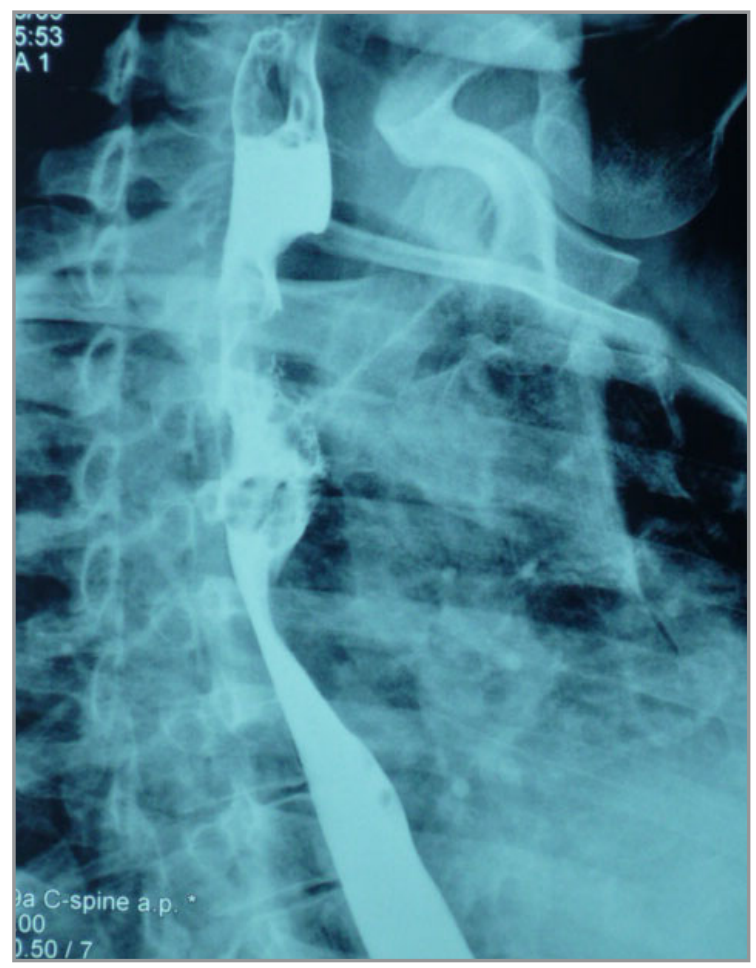

Figure 1. Barium esophagogram showing a $4 \mathrm{~cm}$ long stricture with a smooth surface in the $1 / 3$ proximal esophagus 


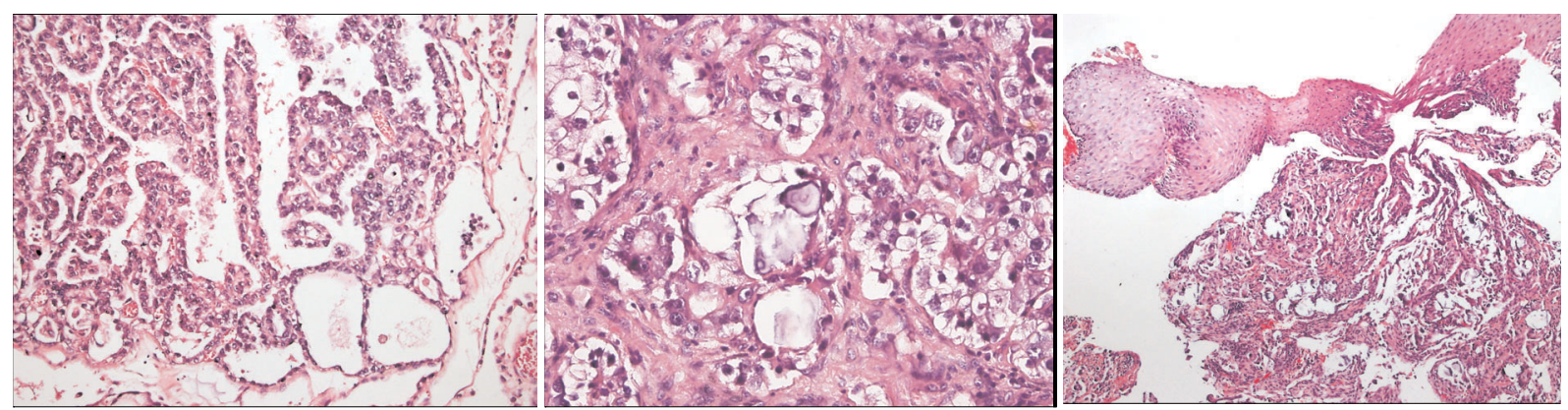

Figure 2. An adenocarcinoma with primarily papillary features was seen in the reexamination of the material from the ovary (a). Metastatic cervical lymph node contained an adenocarcinoma with predominantly clear cell features but psammoma bodies also (b). Esophageal biopsy shows adenocarcinoma infiltration under intact squamous epithelium with psammoma bodies (c).

puted tomography of thorax. Because of progression platin based chemotherapy with gemsitabin was started to be administered. Nearly one year later progression on the cervical lymph nodes was developed. A fine needle biopsy was performed again and immunohistochemically carcinoma metastasis of the ovary was considered. Chemotherapy containing only taxane(docetaxel) was administered and while she was taking this regimen, dysphagia for the solid food has developed. An esophagogram was taken and at the $1 / 3$ proximal of the esophagus, an approximately $4 \mathrm{~cm}$ in length, irregular segment that made the tractus narrow was determined (Figure 1). At the upper gastrointestinal endoscopic exam, a vegetating mass with irregular limits that could'nt permit the endoscope to pass forward was seen. A biopsy was performed endoscopically. Pathologic samples of primary ovarian carcinoma, metastatic cervical lymph nodes and esophagus were examined together (Figure 2). Four blocks of tumor tissue from the ovarian mass contained a primarily papillary adenocarcinoma with some areas of clear cell change. Tumor from the cervical mass contained more of the clear cell areas in addition to some papillary formations and psammoma bodies. Because of the presence of psammoma bodies, thyroglobulin, TTF1 immunohistochemical stainings were performed, but were negative. Mammoglobulin, GCDFP15, and ER immunostainings for a breast primary were also found to be negative. Tumors from both the cervical metastasis and the esophagus were CA125 positive and consistent with metastasis of the ovarian carcinoma. For searching other distant metastases positron emission tomography was taken and bilateral cervical, mediastinal, intraabdominal, paratracheal and at the proximal esophagus increased FDG uptake was found. Our patient is currently taking docetaxel.

\section{DISCUSSION}

Metastatic involvement of the esophagus from a distant primary lesion is rare. In a report of cases from Mizobuchi and et al. the incidence of metastatic esophageal tumors in patients undergoing esophagectomies was $0.2 \%$, but their autopsy data showed that $6.1 \%$ of the patients had metastasis to the esophagus and in $67.8 \%$ of these, the metastatic tumors were detected only by microscopic examination. ${ }^{5}$ In autopsy series, the incidence of secondary esophageal involvement by a variety of primary neoplasms has been reported to range from 0.3 to $3.2 \% .^{2,6,7} \mathrm{~A}$ wide variety of tumors from various organs,such as the breast, larynx, thyroid, hypopharynx, stomach and others, have been reported. ${ }^{2,8,9}$

Metastatic esophageal carcinomas usually pose a diagnostic challenge because, at times, they are indistinguishable from primary esophageal carcinomas. In our case the endoscopic image looked like a primary tumor of the esophagus but showed intact mucosa histopathologically. Therefore, the correct diagnosis can be made only by histopathological examination. When an esophageal stricture with normal mucosa is encountered, a metastatic tumor must be taken into consideration, especially when the patient has a past history of a malignant tumor. In addition, barium esophagography makes an important contribution to the correct diagnosis. On ba- 
rium swallow, a smooth concentric esophageal stricture is often apparent. But in our case although barium esophagography was consistent with a primary tumor, histopathological diagnosis was metastatic adenocarcinoma. Probability of a second primary tumor of the esophagus in our patient was ruled out by the histologic type of the tumor not being the common seen squamous cell carcinoma or intestinal type adenocarcinoma of the esophagus.

As most patients with metastasis to the esophagus already have metastasis to other areas, the treatment of choice is usually chemotherapy and/or radiotherapy ${ }^{8-10}$ Surgical resection has been performed for local control of the disease. The placement of an esophageal prosthesis during the course of radiation therapy and/or chemotherapy is reported to be the treatment of choice for maintaining esophageal patency. ${ }^{11}$

Kerr and Cadman reported that thoracic involvement was found in $44.5 \%$ of 357 ovarian cancer patients, but no esophageal involvement was mentioned in their report, however. ${ }^{12}$ The prognosis for such patients is poor: only $5.6 \%$ of patients survived for 5 years. Dauplat et al ${ }^{13}$ also reported poor prognosis for patients with distant metastasis from ovarian carcinoma. In our case the interval between surgery for primary cancer and dysphagia onset was 8 years and therefore the primary tumor was considered to be slow growing. A surgical approach appears to be the therapeutic procedure of choice for metastatic esophageal carcinoma for resectable cases when the primary tumor growth rate is suspected to be slow. Our case was evaluated for surgery but she was considered inoperable. Of course, the decision to resect such metastatic lesions should only be made after careful and prudent evaluation to ensure clinical benefit to the patients.

\section{REFERENCES}

1. Garusi diG, Donati E. Carcinoma metastatico dell'esofago. Fracastoro 112: 117-138, 1969.

2. Toreson WE. Secondary carcinoma of the esophagus as a cause of dysphagia. Arch Pathol 38: 82-84, 1944.

3. Shimada Y, Imamura M, Tobe T. Successful esophagectomy for metastatic carcinoma of the esophagus from breast cancer-a case report. Surg Today 19: 8285, 1989.
4. Papadimitriou J, Smyrniotis B, Condis J, Antoniou ST. Metastatic mixed mullerian tumour of the esophagus. Int Surg 74: 195-197, 1989.

5. Mizobuchi S, Tachimori $\mathrm{Y}$, Kato $\mathrm{H}$, et al. Metastatic esophageal tumors from distant primary lesions: Report of three esophagectomies and study of 1835 autopsy cases. Jpn J Clin Oncol 27: 410-414, 1997.

6. Abrahms HL, Spiro R, Goldstein N. Metastases in carcinoma: Analysis of 1000 autopsied cases. Cancer 3: 74-85, 1950.

7. Telerman A, Gerard B, Van den Heule B, Bleiberg $\mathrm{H}$. Gastrointestinal metastases from extra-abdominal tumors. Endoscopy 17: 99-101, 1985.

8. Fisher MS. Metastasis to the esophagus. Gastrointest Radiol 1: 249-251, 1976.

9. Atkins JP. Metastatic carcinoma to the esophagus endoscopic considerations with special reference to carcinoma of the breast. Ann Otol Rhinol Laryngol 75: 357-367, 1966.

10. Polk HC, Camp FA, Walker AW. Dysphagia and esophageal stenosis: Manifestation of metastatic mammary cancer. Cancer 20: 2002-2007, 1967.

11. Boccardo F, Merlano M, Canobbino L, et al. Esophageal involvement in breast cancer-report of six cases. Tumori 68:149-153, 1982.

12. Kerr VE, Cadman ED. Pulmonary metastases in ovarian cancer: Analysis of 357 patients. Cancer 56:12091213, 1985.

13. Dauplat J, Hacker NF, Nieberg RK, et al. Distant metastases in epithelial ovarian carcinoma. Cancer 60:1561-1566, 1987.

\section{Correspondence}

Dr. Erkan ARPACl

Ankara Onkoloji Eğitim ve Araştırma Hastanesi

1. Tıbbi Onkoloji Kliniği

Vatan Caddesi

Demetevler, Yenimahalle

Ankara / TURKEY

Tel: (+90.312) 3360909

e-mail: doktorerkan2001@yahoo.com 